Original scientific article

UDC: $613.94(71)(091)$

$323.14(71)(091)$

228301324

DOI 10.25106/AHM.2016.0912

\author{
Erna Kurbegović \\ Department of History \\ University of Calgary \\ SS607, 2500 University Dr. N.W.Calgary, AB, T2N 1N4, Canada \\ E-mail: ekurbego@ucalgary.ca
}

\title{
EUGENICS IN CANADA: A HISTORIOGRAPHICAL SURVEY*
}

\begin{abstract}
While Canada has a rich and complex eugenics history, historians did not begin to unearth it until the 1990s, when Angus McLaren published the only overview Our Own Master Race: Eugenics in Canada, 1885-1945. Since McLaren's landmark study, historians have primarily focused on the history of sexual sterilization legislation prior to 1945. In particular, the Sexual Sterilization Act (1928) in the province of Alberta has been closely analyzed by scholars, who have placed the eugenics movement in the province within the larger context of social reform movements. Historians have also drawn scholarly attention on eugenics in the second half of the twentieth century focusing on Alberta's long eugenic history, as well as connecting the early movement in Canada with the current discussion about reproductive rights and choice. This article provides a historiographical overview of the approaches (legal, social, cultural)employed by Canadian historians to map Canada's eugenic history.
\end{abstract}

Key Words: Eugenics, Canada, Historiography

Non-MeSH: Sexual Sterilization

During the late $19^{\text {th }}$ and early $20^{\text {th }}$ centuries the impact of urbanization, industrialization, wars, declining birth rates, and declining overall health of the population in many Western countries led to an ongoing preoccupation ofprofessionals, social reformers, and politicians with "race degeneration". Similar to other Western countries, these developments produced significant changes in the social, political, and economic spheres in Canada and often led to social tensions and problems. The theo-

\footnotetext{
* I would like to express my gratitude to Avram Lytton for his comments and suggestions that greatly improved the manuscript.
} 
ries about race degeneration were exacerbated by social concerns of many of Canada's reformers and professionals, who used, and often misapplied, scientific theories to support their "progressive" position. The concerns over race degeneration were linked to the larger international eugenics discourse that encouraged the reproduction of the "fit" (intelligent, strong, upper-middle class individuals) and discouraged the "unfit" (the poor, mentally and physically disabled, new immigrants, and other vulnerable groups) from reproducing [1]. Eugenics, according to the late historian Richard Soloway, "gave scientific credibility (...) to (...) prejudices, anxieties, and fears that were (...) prevalent primarily (...) among the middle and upper classes" [2].

Canada is an interesting case study as it represents a conversion zone between British and American eugenics. Canadians shared similar concerns as their British counterparts about national "unfitness," which they contributed to a variety of social issues including poverty. Further, Canadian were influenced by Francis Galton's ideas of social purity and race betterment and sought to apply them in Canada [1]. Similarly, Canadian eugenics was shaped by the American influence as both were immigrant nations and the eugenics movement must be understood within the context of increased immigration to both countries at the end of the $19^{\text {th }}$ and at the beginning of the $20^{\text {th }}$ century. Xenophobia and racism in both countries affected immigration policy during this period [3].The United States also served as a model for eugenic legislation, and found a receptive audience in Western Canada, particularly in the provinces of Alberta and British Columbia as these were closer geographically to the United States than Canada's East [4]. Alberta passed legislation on eugenic sterilization in 1928, and British Columbia followed in 1933. Alberta would go on to implement one of the most aggressive eugenics policies in Canada. Between 1929 and 1972, when the Alberta's Sexual Sterilization Act was repealed, over 2800 individuals were sterilized under Alberta's eugenics program. Less is known about British Columbia's eugenic past as many of the records were either lost or destroyed following the repeal of the legislation in 1973 [5].

While Canada has a rich and complex eugenics history, historians did not begin to unearth it until the 1990s, when historian Angus McLaren published the only overview Our Own Master Race: Eugenics in Canada, 1885-1945. Prior to this, much of the literature was written by legal scholars and scientists who provided analyses and critiques of Alberta's eugenic legislation. A handful of these works were published following the repeal of Alberta's sterilization Act in 1972 by a newly elected Progressive Conservative government. Scholars did not look at this history again until the 1990s within the context of the Muir v. The Queen trial (described below). Despite the increased volume of literature in the recent years on the history of eugenics in Canada, it suffers from a number of shortcomings having to do with localization and heavy focus on the province of Alberta due to its aggressive eugenics program. While the emphasis on Alberta is important and necessary, it nevertheless overshadows other Canadian provinces that did not implement a eugenics program but still engaged in eugenic discourse. Studying other Canadian provinces and their 
unique local conditions will tell us more about the determinants and formulations of eugenics policy. This will highlight the ways in which similar themes about fitness, nationhood, and racial betterment emerged in other locations and how these ideas crossed provincial boundaries back and forth.

\section{Eugenics in Canada}

The negative effects of industrialization and urbanization at the turn of the $20^{\text {th }}$ century (overcrowding, pollution, deteriorating health among the poor and workers) were seen by many Canadians as fuelling national degeneration and threatening the make-up of Canadian society. This concern was further exacerbated with the arrival of new immigrants, particularly those from Eastern Europe. In the 1890s, the Canadian government implemented an aggressive immigration policy to settle the Canadian west. The increase in non-Anglo Saxon immigrants arriving in Canada brought out nativism and racism among English Canadians [6]. Many Canadians were determined to keep Canada white and Protestant, and to only accept immigrants from "desirable" countries such as Britain and the United States. This was because English Canadians assumed that white Anglo-Saxons were a superior race, with superior traditions and customs that those with non-Anglo Saxon background would have a difficulty adjusting to. But even this "acceptance" is complex as Canadian officials wanted individuals who were eugenically fit, and were less keen to accept poor and working class individuals arriving from Britain or the United States, who they believed might be a drain on the economic system $[1,21]$. Here we can see the influence of British eugenics that tended to differentiate the fitness of an individual based on their social class [7]. By 1900, Canadian eugenicists started to push for tighter immigration restrictions, and amendments to the Immigration Act, following this period, tended to be laced with eugenic language [8]. As historian Angus McLaren has shown, eugenicists did not view themselves as nativists, instead they argued that restrictions on immigration to keep the eugenically unfit out "would not be based on prejudice, personal bias, or old-fashioned notions of patriotism but rather on progressive, sophisticated, and scientifically informed analyses of the worth of individual immigrants" [1]. In reality, these types of arguments positioned the new immigrants as targets of eugenics campaigns, and provided justification for the class and race biases of many English Canadians of that period.

\section{Approaches to Eugenics History in Canada}

Scholars first started to write about eugenics in Canada in the late 1960s and 1970s within the context of Alberta's long eugenics program and criticisms to it. In 1969, three years before the repeal of the Sexual Sterilization Act, geneticists K.G. McWhirter and J. Weijer provided a scientific critique of Alberta's eugenic legislation and questioned its construction which they claimed was based on an outdated and basic understanding of genetics [9]. Due to a flawed understanding of genetics, they 
argued, along with a broad view of what constituted "mental deficiency," the Alberta eugenics program targeted vulnerable, "young, poor [and] uninfluential" individuals [9]. Critiques to Canadian eugenics began in the 1930s and were primarily voiced by the Roman Catholics and the scientific community, particularly geneticists and biologists. The latter presented the eugenicists with scientific "facts" and argued that heredity was much more complex than the eugenicists claimed. At this point, scientists were aware that the majority of those deemed "feebleminded" had "normal" parents. Therefore, eugenic measures would not lead to an improvement of the race and society $[1,8]$. By the end of the Second World War and once the Nazi atrocities came to light, eugenics policies were increasingly discredited in the post-1945 period because of their association with Nazi Germany [1]. But despite this development, the eugenics program in Alberta continued. While more work still needs to be done on the years before the repeal of the Sexual Sterilization Act, Sociologist Jana Grekul provides some reasons for the longevity of the program: prosperity and economic growth, lack of strong opposition, and a strong populist government ensured that Alberta's eugenics program continued until 1972. The program ended only after the election of a new government [5].

Around the time that McWhirter and Weijer were working on their article, Alberta's government set up a commission under W.R.N. Blair to study mental health in the province. While the report, released in 1969, had many recommendations for improvement of Alberta's mental health system, it had little to say about the province's eugenics program. According to one local newspaper report "the provincial eugenics board sailed through the scrutiny of the Blair committee and came out smelling like a rose" [10]. McWhirter and Weijer's article then was a timely critique when there were was little public discussion of Alberta's eugenics program.

The publication of McWhirter and Weijer's study influenced the Progressive Conservative party in Alberta to adopt the repeal as a part of their platform. They attacked the Sexual Sterilization Act on legal and scientific grounds, and concluded that the Act needed to be repealed as it violated human rights [11]. Following the election of the Progressive Conservative government under Peter Lougheed in 1971, the Act was repealed a year later. Due to this development, a number of studies emerged dealing with eugenics in Alberta. In his 1974 honour's thesis, Timothy Christian provides a legal perspective on Alberta's eugenic legislation. He examines the provincial Eugenics Board's case files and shows that the majority of the cases presented to the Board were vulnerable and marginalized groups, including Eastern European immigrants, Aboriginal people, women, and the poor. He also discusses the 1937 and 1942 amendments $^{1}$ to the Act and suggests that these amendments faced little opposition because Albertans were primarily occupied with events unfolding in Europe [12]. Legal scholar, Bernard M. Dickens analyzes the legality of eugenics and

1 The 1937 amendment allowed the Alberta Eugenics Board to sterilize patients without consent. The 1942 amendment allowed for the sterilization of a broader category of mentally ill patients including those with syphilis, epilepsy, and Huntington's chorea. 
criticizes the Alberta legislation, arguing that "it was permeated with biological and social fallacies, and was more a product of anti-science than of science" [13]. The work of legal scholars laid the foundation for historians constructing the history of eugenics in Alberta. Building on Christian's work, historian Terry Chapman traces the developments leading up to the implementation of the Sexual Sterilization Act and argues that increased immigration to Western Canada played a role in the passing of the Act [14]. As noted above, the increase in population led to the emergence of nativist sentiments among many middle class reformers in Canada's west who were eager to keep Canada white, Anglo-Saxon, Protestant [7].

Historians did not approach the topic of eugenics again until 1990 when social historian Angus McLaren published Our Own Master Race: Eugenics in Canada 1885-1945. McLaren's study provides an overview of eugenics on the national scale and explores the motives behind the "race betterment" campaign of many Canadian social and medical eugenicists, and shows that many prominent Canadians (famous feminists, politicians, social reformers, and medical professionals) were fascinated by eugenic ideas [1]. The 1990s also represent a period when sterilization survivors first publicized their experience and mistreatment under Alberta's eugenic program. In 1995, an Alberta woman, Leilani Muir (1944-2016) sued the Alberta government for wrongful sterilization. In Muir v. The Queen, Madam Justice Joanne B. Veit ruled in favour of the plaintiff [15]. Following Muir's trial, hundreds of other sterilization survivors filed suits against the province [8]. This politically charged context prompted historians to delve deeper into Alberta's eugenic past.

Since the mid-1990s, Canadian historians have focused on the history of sexual sterilization legislation prior to 1945. Legal scholars Timothy Caulfield and Gerald Robertson have built upon Timothy Christian's 1974 work. They examine the Alberta Sexual Sterilization Act and discuss the social forces which influenced its implementation in 1928 [16]. Sociologists Jana Grekul, Harvey Krahn, and David Odynakalso build on Christian's study through a statistical analysis of Alberta Eugenics Board's case files to determine which targeted groups were overrepresented as victims of involuntary sterilization. They concluded that women, the young, and Aboriginals were particularly targeted by Alberta's eugenics program but challenged Christian's argument that the program discriminated against Eastern European immigrants [5]. Historian Mikkel Dack focuses on the 1937 amendment to the Act and challenges previous scholarly interpretations regarding the lack of public opposition to it. Dack suggests that the 1937 amendment must be understood within the social, political, and cultural context of the 1930s rather than just as an extension of the 1920s eugenics movement [4].

In particular, the sterilization Act in Alberta has been meticulously analyzed by scholars who have placed the eugenics movement in the province within the larger context of social reform movements. In his work, Angus McLaren has demonstrated that many of Canada's well-known social reformers and feminists were also ardent eugenicists who played a significant role in lobbying provincial governments for eu- 
genic legislation [1]. Psychologists Erin Moss and Hank Stam examine the relationship between first wave feminism and eugenics by focusing on Alberta as a case study. Moss and Stam argue that the supposed threat of feeblemindedness led to the marriage of feminism with the eugenics movement. Many women reformers had overlapping memberships in various organizations that had similar goals as the eugenics movement: to prevent social degeneration and to slow down the pace of social change. In this sense, eugenics fell into the "woman's sphere" since Anglo-Saxon women were seen as "mothers of the race," and it was their duty to preserve that race [17]. In the same vein, historian Sheila Gibbons provides an analysis of agrarian feminism and eugenics in Alberta and shows how "the agrarian identity and feminism linked together more broadly in the province through their desire to create a better nation through the physical and the mental improvement of the individual" [18].Working within an agrarian society, women's agrarian organizations such as the United Farm Women of Alberta (UFWA) were able to exert significant influence on the provincial government and push for a greater role in the provincial health care system [18].

Scholars have also drawn attention on eugenics in the second half of the twentieth century focusing on Alberta's long eugenic history, as well as connecting the early movement in Canada with the current discussions about reproductive rights and choice. Examining the relationship between eugenics and gender, Sociologist Jana Grekulhas shown that the majority of the cases presented to the Alberta Eugenics Board were women, and their sexual behaviour was much more scrutinized than that of men. Often "mentally normal" women were presented to the Eugenics Board because, as Grekul suspects, they were viewed as sexually deviant and as posing a challenge to the established gender norms. In this way, women and men were sterilized for different reasons, but women were overrepresented among those sterilized [19]. Continuing with a focus on gender, historian Amy Samson discusses the often overlooked relationship between eugenics and the female-dominated professions such as social work, education, and public health nursing. Samson shows that these professional women used their access to families and schools to present themselves as "experts" in this field and thus as important players in the eugenics movement. Similar to the male dominated medical profession, these women also used the eugenics movement to enhance the status of their respective professions [20]. Bridging eugenics, gender, and sexuality, social historian Erika Dyck'swork Facing Eugenics: Reproduction, Sterilization, and the Politics of Choice traces, through case studies, ideas about masculinity, femininity, consent, and reproductive choices that impacted individuals who either voluntarily or coercively underwent sexual sterilization in Alberta. While sterilization was often tied to the eugenics program, Dyck shows that many women sought sterilization as birth control and thus took control over their own reproduction [7]. Dyck's work not only contributes to an understanding of eugenics in Alberta in the post-1945 period, but it also gives a voice to those most affected by sterilization programs, and connects eugenics to 
twentieth century debates about reproductive rights and choice, genetic research, and autonomy.

While these scholars have offered important insight into the history of eugenics in Alberta, and Canada in general, there still remains a strong historiographical need to further address the unique local conditions (demographics, politics, social and cultural conditions) that contributed to the adoption or rejection of eugenics programs in other parts of Canada.Recently, historians have also started to unearth the eugenic past of other Canadian regions, although there is still more work to be done. Historian Leslie Baker's work traces the link between public health initiatives and eugenics through the lens of the Halifax Explosion of 1917. Baker argues that while reformers in Halifax did not promote eugenic sterilization, their public health reforms targeted marginalized groups for institutionalization and surveillance, particularly following the Halifax Explosion [21]. Continuing with public health, historian Erna Kurbegovićs case study on the province of Manitoba analyzes the public health initiatives of the Canadian National Committee for Mental Hygiene after the First World War. Kurbegović argues that through the employment of mental hygiene surveys and its disease prevention campaign, the committee not only influenced institutional reform but also spread eugenic ideology across provincial boundaries [22]. Similarly, historian C. Elizabeth Koester explores the role played by the 1917 Ontario Royal Commission on the Care and Control of the Mentally Defective and FeebleMinded in understanding eugenics in Ontario. She suggests that the Commission did have an impact on eugenics in Ontario by focusing on social reform issues of interest to eugenicists but at the same time, by limiting the discussion of eugenic sterilization, the commission kept it out of the public discourse at that time [23]. What these works show is the overlap between eugenics and public health in different Canadian regions. As American historian Martin Pernick has suggested "public health agencies and eugenics organizations often overlapped in goals and methods, programs, and personnel. Many public health institutions included eugenics in their official duties" [24]. By analyzing the connections between eugenics and public health, and moving beyond the focus of involuntary sterilization legislation, Canadian historians can explore other angles to the history of eugenics.

One of those angles is the political opposition to eugenics particularly from the Roman Catholics in Canada. This had been overlooked until recently by historians of eugenics in Canada. In his overview, Angus McLaren suggests that a strong Catholic opposition in Manitoba and Quebec prevented the implementation of any eugenic legislation [1]. Historian Sebastian Normandin paints a more complex picture of Catholic resistance in Quebec by suggesting that while the Church doctrine opposed any measure that limited reproduction, it had little to say about positive eugenics. In addition, he shows that the resistance to eugenics primarily came from Frenchspeaking Catholics who objected on cultural and religious grounds [25]. Erika Dyck provides a sample of the Roman Catholic opinion on eugenics in the province of Saskatchewan through an analysis of a Catholic newspaper the Prairie Messenger. She 
shows that the paper's approach to eugenics was sometimes softened particularly in their response to marriage of those deemed to be "mentally defective." At other times, it stuck strictly to the Catholic doctrine [7]. With their work, these historians have pointed to an area of research in the history of eugenics that has not received much attention from Canadian historians. What was the influence of the Roman Catholics on eugenics in Canadian provinces? Was there Catholic resistance in Alberta? How did the response to eugenics vary among French-speaking and English-speaking Catholics? How important was the international environment to the Roman Catholic resistance in Canada? These are questions that future researchers will need to address in providing a more thorough understanding of the Catholic struggle with eugenics.

\section{Conclusion}

After reviewing the literature on eugenics in Canada, it is clear that the scholarship was often shaped by larger political contexts including the increasing challenges to eugenics on scientific and legal grounds following the Second World War, the coming forward of sterilization survivors in the mid-1990s that uncovered details of Alberta's eugenic program unknown to many, lastly, the literature is also shaped by current discussions about reproductive choices and rights, medical ethics, and genetic screenings and research. All of these contexts prompted historians to further investigate Canada's eugenics history. Due to Alberta's long and aggressive eugenics program, much of the scholarship has focused on that province, but as noted above, historians are also working on documenting the ways in which eugenic discourse impacted social policy and penetrated into other areas of the community, including public health organization.

Future research should focus on several areas: First, as Timothy Christian and Jana Grekul show in their studies, Canada's Aboriginal people were overrepresented among sterilization cases in Alberta $[5,12]$ and this fact cannot be divorced from Canada's discriminatory colonial policies. Historians Carolyn Strange and Jennifer Stephen demonstrate that through this colonial lens, eugenicists "linked 'Indian blood' to low intelligence [and] were predisposed to diagnose indigenous people as 'mentally defective' and incompetent: consequently they were judged unfit to make their own reproductive decisions" [8]. It is evident that detailed analyses of the Indigenous experiences under Alberta's eugenics program are necessary. ${ }^{2}$ Secondly, Philosopher and Director of the multi-centre research project "Living Archives on Eugenics in Western Canada" (2011-2015), Robert Wilson shows the importance of oral history in constructing Canada's eugenic past. The sterilization survivors' stories

2 While not dealing exclusively with Alberta's eugenics program, historian Karen Stote has linked the forced sterilization of Indigenous women in Canada to colonial policies that sought to dispossess Indigenous people and lower their numbers. Stote K. An Act of Genocide: Colonialism and the Sterilization of Aboriginal Women. Winnipeg. Fernwood Publishing; 2015. 
were central to that project and their accounts show that "there is much more to eugenics than sterilization and its aftermath for those who have survived it" [26]. Lastly, future studies should also analyze the political resistance to eugenics in Canadian provinces. As seen above, the Roman Catholics were the most active in opposing eugenic legislation, yet there have been little written about their activism in this respect. Was there resistance from immigrant and working class communities across Canada? If so, how, and through what channels, did they voice their opposition? This would be interesting to analyze as we know that these groups tended to be targets of the eugenics campaigns. All of this suggests that Canada's eugenics history is worthy of study, and similar to other places, Canadian eugenics manifested itself in a variety of ways and significantly impacted state policies.

\section{Summary}

This article provides an overview of the eugenics historiography in Canada. Scholars first started to write about Canada's eugenics past in the 1960s and 1970s providing legal and scientific challenges to Alberta's Sexual Sterilization Act. Historians did not begin to exploreCanada's eugenics history until the 1990s, when Angus McLaren published the only overview, Our Own Master Race: Eugenics in Canada, 1885-1945. This article shows that despite the increased volume of literature in recent years, it has nevertheless suffered from shortcomings, primarily dealing with localization and a heavy focus on the province of Alberta due to its aggressive eugenics program. As this article demonstrates, historians are also working on documenting the ways in which eugenic discourse impacted social policy and penetrated into the community in other Canadian provinces. This highlights the ways in which similar themes about fitness, nationhood, and racial betterment emerged in other locations and how these ideas crossed provincial boundaries back and forth. In writing about Canada's eugenics history, scholars were often influenced by larger social and political events that unfolded in the country, includingmounting criticism of eugenics in the 1960s and 1970s, the repeal of Alberta's Sexual Sterilization Act in 1972, and the coming forward of sterilization survivors in the 1990s to tell their stories. These events unearthed valuable information that prompted historians to further investigate Canada's eugenics past. This article also provides direction for future research including a discussion of Aboriginal experiences under Alberta's eugenics program, a further analysis of political resistance to eugenics, including that of the Roman Catholics, and an emphasis on oral history that allows for an understanding of the broader impacts of eugenics on the sterilization survivors.

\section{References}

1. McLaren A. Our Own Master Race: Eugenics in Canada, 1885-1945. Toronto. McClelland \& Stewart; 1990.

2. Bland L, Hall LA. Eugenics in Britain: The View from the Metropole. In: Bashford A, Levine P, editors. The Oxford Handbook of the History of Eugenics. Oxford. Oxford University Press; 2010.

3. Dowbiggin I. Keeping America Sane: Psychiatry and Eugenics in the United States and Canada, 1880-1940. Ithaca. Cornell University Press; 1997. 
4. Dack WM. The Alberta Eugenics Movement and the 1937 Amendment to the Sexual Sterilization Act. Past Imperfect. 2011; 17: 90-113.

5. Grekul J, Krahan H, Odynak D. Sterilizing the "Feeble-minded": Eugenics in Alberta, Canada, 1929-1972. Journal of Historical Sociology. 2004; 17: 358-384.

6. Samson A. Eugenics in the Community: The United Farm Women of Alberta, Public Health Nursing, Teaching, Social Work, and Sexual Sterilization in Alberta, 1928-1972 (PhD Dissertation). Saskatoon. University of Saskatchewan; 2014.

7. Dyck E. Facing Eugenics: Reproduction, Sterilization, and the Politics of Choice. Toronto. University of Toronto Press; 2013.

8. Strange C, Stephen J. Eugenics in Canada: A Checkered History, 1850s-1990s. In: Bashford A, Levine P, editors. The Oxford Handbook of the History of Eugenics. Oxford. Oxford University Press; 2010.

9. McWhirter KG, Weijer J. The Alberta Sterilization Act: A Genetic Critique. University of Toronto Law Journal. 1969; 19: 424-431.

10. The Edmonton Journal, April 12, 1969.

11. Grekul J. The Social Construction of the Feebleminded Threat: Implementation of the Sexual Sterilization Act in Alberta, 1929-1972 (PhD Dissertation). Edmonton. University of Alberta; 2002.

12. Christian T. The Mentally Ill and Human Rights in Alberta: A Study of the Alberta Sexual Sterilization Act (PhD Dissertation). Edmonton. University of Alberta; 1974.

13. Dickens BM. Eugenic Recognition in Canadian Law. Osgood Hall Law Journal. 1975; 13: 547- 577.

14. Chapman T. The Early Eugenics Movement in Western Canada. Alberta History. 1977; 25: 9-17.

15. Wahlsten D. Leilani Muir versus the Philosopher King: Eugenics on trial in Alberta. Genetica. 1997; 99: 185-198.

16. Caulfield T, Robertson G. Eugenics Policies in Alberta: From the Systematic to the Systemic? Alberta Law Review. 1996; 35: 59-79.

17. Moss E, Stam H. From Suffrage to Sterilization: Eugenics and the Women's Movement in $20^{\text {th }}$ century Alberta. Canadian Psychology. 2013; 54: 105-114.

18. Gibbons S. Our Power to Remodel Civilization: The Development of Eugenic Feminism in Alberta, 1909-1921. Canadian Bulletin of Medical History. 2014; 31: 123-142.

19. Grekul J. Sterilization in Alberta, 1928-1972: Gender Matters. Canadian Review of Sociology. 2008; 45: 247-266.

20. Samson A. Eugenics in the Community: Gendered Professions and Eugenic Sterilization in Alberta, 1928-1972. Canadian Bulletin of Medical History. 2014; 31: 143-163.

21. Baker L. A Visitation of Providence: Public Health and Eugenic Reform in the Wake of the Halifax Disaster. Canadian Bulletin of Medical History. 2014; 31: 99-122.

22. Kurbegović E. The Influence of the Manitoba Mental Hygiene Survey, 1918. Western Humanities Review. 2015; 69: 298-323.

23. Koester CE. An Evil Hitherto Unchecked: Eugenics and the 1917 Ontario Royal Commission on the Care and Control of the Mentally Defective and Feebleminded. Canadian Bulletin of Medical History. 2016; 33: 59-81. 
24. Pernick M. Eugenics and Public Health in American History. American Journal of Public Health. 1997; 87: 1767-1772.

25. Normandin S. Eugenics, McGill, and the Catholic Church in Montreal and Quebec: 18901942. Canadian Bulletin of Medical History. 1998; 15: 59-86.

26. Wilson RA. The Role of Oral History in Surviving a Eugenic Past. In High S., editor. Beyond Testimony and Trauma: Oral History in the Aftermath of Mass Violence. Vancouver. University of British Columbia Press; 2014.

Submitted: 1. 12. 2016.

Reviewed: 4. 12. 2016.

Accepted: 9. 12. 2016. 